\title{
An author report: Elfreda Annmary Chatman
}

\author{
Murat Erkan Eren ${ }^{1}$
}

\begin{abstract}
The main aim of this report is to become familiar with Elfreda A. Chatman and her major works and theories. She has contributed information science by producing several theories such as "the theory of information poverty," "the normative behavior theory" and "the theory of life in the round" and implemented many studies about information seeking behavior of ordinary people. Although her major is library and information science, she focused on women in prison, the feminist movement, poor workers and janitors at large universities by using an ethnographic perception. She emphasized their information seeking behaviors in small communities and tried to describe their approach about information poverty. Also, she studied public libraries and the role of mentorship of the library leaders. The findings she found in her studies are useful not only for information science but also other disciplines such as sociology and psychology.
\end{abstract}

Keywords: Author report; information science; knowledge sharing; information seeking behavior; women prisoners.

\section{Introduction}

Chatman focused on poor workers $(1985,1987)$, retired women (1992), female prisoners (1999), janitors $(1990,1991)$, the online world of some people (2001), and feminist booksellers (2001) as well as librarians (1992). She emphasized their information seeking behaviors and attitudes by applying other disciplines such as ethnography. Although Chatman has derived benefits from other disciplines' theories in her first studies, she noticed that the theories belonging to other disciplines are inadequate to explain some problems in the field of information science. Hence, she improved three theories: the theory of information poverty, the theory of life in the round and the theory on normative behaviour (Burnett, Besant, \& Chatman, 2001). She tried to define characteristics of ordinary people and their information seeking behaviour. She characterized daily information sharing in various small communities that she called "small world" (Chatman, 1996). She asserted that the people in this environment can neglect information from outside because they do not believe in the effectiveness of this kind of information in this small world. Also, they suppose that if they ask for information, others can perceive them as deficient. Chatman claims that the life in small communities is foreseeable, and the members of the community have general ideas that are determined by the community. Their ideas, values and attitudes are similar, and this similarity is a condition to being accepted by the community (Chatman, 1999). The community concluded that the information from outside is not valuable for the individuals. The community uses the norms in order to shape members, thus causing normative behaviours. Many researchers found Chatman's theories vital to explain information seeking behaviour in small communities. Therefore, these articles are Chatman's most cited works. Researchers who

\footnotetext{
1.Ph.D., Turkish National Police, muraterkaneren@yahoo.com
} 
Eren, M. E. (2016). An author report: Elfreda Annmary Chatman. International Journal of Human Sciences, 13(1), 844-850. doi:10.14687/ijhs.v13i1.3642

commonly study in the field of library and information science, information system and computer science cited Chatman. These findings prove the importance of her works for information science. Even though their works were cited mostly in USA and Canada, some researchers who cited her works are from Finland, England and Australia. These results show that she is an internationally accepted scientist in this field.

\section{Literature review}

Elfreda A. Chatman had begun the SLIS faculty in Youngstown State University before had her M.S.L.S from Case Western Reserve University. Next, she earned her Ph.D. from the School of Library and Information Studies in University of California, Berkeley. The subject of her dissertation was information diffusion between poor employees, and she won the ALISE (American Library and Information Science Education) Best Dissertation Award in 1984 with this dissertation. Chatman lectured 13 years at various universities. She taught as a professor at the University of North Carolina at Chapel Hill until 1998. Her last school was the Florida State University before she passed away in 2002. Dr. Chatman served in the LLRT as a member between 1980s and 1990s; afterwards, he became chair in 1993-1994 in this organization. Also, she won the Association of College and Research Libraries (ACRL) best book award in 1995 with her book named "The Information World of Retired Women" that published in 1992 by Greenwood Press. She mostly focused on the information theory and information-seeking behaviors and the needs of ordinary people by using ethnographic approach in her lessons and studies.

It can be a reasonable approach to review major works of the author to recognize her interest fields and to consider her approaches. Chatman's well-known study is "The Impoverished Life-World of Outsiders". She investigated a lower socioeconomic class who lived in a specific district. She applied social network theory in order to find out their approaches about information needs and information seeking (Chatman, 1996). She was influenced by some discussions that tried to clarify the relationship between economic poverty and information shortage at the beginning of her research. She concluded that there is no association between two concepts (p.194). She benefited from these four conceptions: deception, risk taking, secrecy, and situational relevance in her study. Also, she asserted that information seeking and sharing attitudes are determined by the norms of the community in the world of poor people. If the information's source does not belong to this small environment, it can be neglected easily. She recommends improving the relationship between outsiders and insiders. The theory of information poverty made a significant contribution to the field of information science by identify information scarcity and explaining this multifaceted cultural and collective phenomenon (p.205).

In other research called "Small Worlds: Normative Behavior in Virtual Communities and Feminist Bookselling", Chatman observed the world of the virtual societies and feminist booksellers who acted within the organization of Women in Movement (Burnett, Besant, \& Chatman, 2001). They were living different places, and they had dissimilar features socioeconomically and culturally. The normative behavior theory consists of following concepts: social norms, social types, worldview and information behavior that offer a structure for examining the association between human beings' social world and information behavior (p.537). Information behavior has important effects on individuals' attitudes to get to access information or keep away from it. The theory is essential to provide a practical perspective that helps to understand the value of information in the small world of the specific people. Also, due to this theory, it can be figured out that individuals do not tend to gain and share the information, sometimes they avoid having information; therefore, information behavior can be very complex in the small communities (p.545). 
Eren, M. E. (2016). An author report: Elfreda Annmary Chatman. International Journal of Human Sciences, 13(1), 844-850. doi:10.14687/ijhs.v13i1.3642

Chatman has generally studied about women and information poverty. In particular, she examines the life of women in prison and their information seeking behaviors and needs. "A Theory of Life in the Round" is a significant work of Chatman that investigates information's implication on the women in prison and their perspectives about information seeking by interviewing 80 women prisoners. In this study, Chatman aimed to discover the life of female prisoners to flesh out her understanding of information by applying an ethnographic approach and presenting "the theory of life in the round" (Chatman, 1999). In general, society's values and attitudes have no significance in this environment. In fact, if information is associated with the recognized standards, it can be valuable; otherwise, it will most likely be neglected (p.215). The theory claims that information is commonly not accepted from outside. If there is a strong common repute that information is significant or relevant, information can be gained or shared by individuals. In small worlds such as prisons, people's perceptions turn into from personal ideas to a general view by communities in the course of time (p.207). She concluded that the prison is an information world in which people have their special laws to seeking information, and the system works well (p.207).

Even though her most widely known subjects to focus on are the feminist movement, female prisoners and pensioners and their information needs, Chatman has not only studied this field, but also she published several articles about librarians, janitors and workers. In the study of "The Role of Mentorship in Shaping Public Library Leaders," she discussed the significance of mentorship and leadership in the career improvement of librarians. The results shows, both leaders and mentors have important role in this area. (Chatman, 1992). The study of "Alienation Theory: Application of A conceptual Framework to A Study of Information among Janitors" by Chatman analyzed janitors' information behavior and pointed out that janitors don't have an information system to obtain information steadily (Chatman, 1990). The public library was another subject examined by Chatman. In her study of "Small World Lives: Implications for the Public Library" she underlines some concepts such as information behaviors, perceptions and social models that are parts of the field of public libraries (Chatman, 1998) She also emphasized information requirements in the health sector and concluded that employees do not commonly share information. The study of "The Information World of Low-Skilled Workers" Chatman also pointed out that employees do not mostly use libraries (Chatman, 1987). The other research implemented by Chatman is "Life in Small World: Applicability of Gratification Theory to Information-Seeking Behavior" that examined ordinary people's information seeking behaviors and presents the structure of gratification theory that contains some suggestions for information professionals. In a similar way, she investigated ordinary people's information needs. For instance, in her research of "Knowledge Gap, Information-Seeking and Poor", she argued knowledge gap theory by focusing on information seeking behavior among the poor people, and noted that their information requirements is not answered by mass media (Chatman, 1995).

In this report, following questions will be answered:

What are the major works of the author?

Who are her co-authors?

Who are the researchers who cited the author mostly?

Which years are most cited interim for the author?

What are the fields of the researchers who have cited her extensively?

What is the impact of Chatman's studies on information science and other disciplines? Method

I benefited from several citation databases and tools such as CiteSeer (citeseerx.ist.psu.edu), Google Book Search (books.google.com), Google Scholar (scholar.google.com), DBLP indexes and Web of Science to make correct evaluation of the effect 
Eren, M. E. (2016). An author report: Elfreda Annmary Chatman. International Journal of Human Sciences, 13(1), 844-850. doi:10.14687/ijhs.v13i1.3642

and value of Chatman's works. Since every service generates similar outcomes, using numerous citation tools can benefit to evaluate the accurate effects of the author's works. First, I inspected how many times the author has been cited. Second, I tried to find out which works of the authors have been generally cited. These numbers showed that the influence of authors in the field of information science and which works of the authors have been considered important. Third, I looked over who are the researchers who have frequently cited her and what their fields are. Although the author has more than ten works, researchers have only cited her four works. Therefore, I did not need to restrict a certain number of her works. However, I limited the years from 1995 to 2008 because it would be a good idea to skip over the years before 1995. Also I evaluated her articles by just setting apart her book in this study.

\section{Data analysis and results}

Chatman published a number of articles and studies during her whole scholastic life. Between 1995 and 2001, she published six works. It can be seen on Figure 1. I came across 207 records when I investigated about Chatman in Google Scholar. According to Google Scholar's records, the most cited work of Chatman was "The Improvised Life-World of Outsiders," which has been cited 122 times. The following work was her awarded book called "The Information World of Retired Women," which has been cited 65 times.

When we look at the graphs of the published items each year, she issued in 1995, 1996, 1998, and 1999 one research per year and published two pieces of research in 2001. The sum of times cited is 127 . The year of her articles most cited is 2007, and the second most cited year is 2002. 1999, 2005 and 2006 are the years when the author's articles have been cited extensively. The minimum level for citation of author's articles was in 1998. Although in 2008 the author was cited mostly, there is a decrease compared with 2007, see Figure 2.

The most cited article is "The impoverished life-world of outsiders," which 70 times was cited, and the most cited year of this article is 2002. In this year, it was 11 times cited. The second article is "A Theory of Life in the Round" which was cited 39 times. The other articles are "Small worlds: Normative behavior in virtual communities and feminist bookselling" and "A small world lives: Implication for the public library." Those were cited 9 times.

Generally, the authors who have cited Elfreda Chatman published their articles in the field of library and information science (94\%), computer science information system (40\%), communication $(2.5 \%)$ and literature $(1.7 \%)$, see Table 1 . Citation records can be classified according to country: USA (54\%), Canada (20\%), England, Australia and Finland (6\%), see Table 2. Chatman studied together with Burnett, Dawson and Pendleton in her researches as co-author. Her articles have been mostly cited by Pettigrew (6\%), Fisher (5\%), Durrance (4\%), Jaeger (4\%) and Burnett (3\%), see Table 3. As a document type citation records: There are articles $(63 \%)$, proceeding papers $(19 \%)$ and reviews $(16 \%)$, that can be seen on Table 4.

Table 1. Analysis by Subject Area

\begin{tabular}{lccc}
\hline Subject Area & Record Count & $\%$ of 116 & Bar Chart \\
\hline $\begin{array}{l}\text { INFORMATION SCIENCE \& } \\
\text { LIBRARY SCIENCE }\end{array}$ & 110 & $94.8276 \%$ & \\
COMPUTER SCIENCE, & 47 & & \\
INFORMATION SYSTEMS & & $40.5172 \%$ & \\
COMMUNICATION & 3 & $2.5862 \%$ & \\
LITERATURE & 2 & $1.7241 \%$ & $\mathbf{1}$ \\
\hline
\end{tabular}


Eren, M. E. (2016). An author report: Elfreda Annmary Chatman. International Journal of Human Sciences, 13(1), 844-850. doi:10.14687/ijhs.v13i1.3642

Table 2. Analysis by Country/Territory

\begin{tabular}{lccc}
\hline Country/Territory & Record Count & $\%$ of 116 & Bar Chart \\
\hline & & & \\
USA & 63 & $54.3103 \%$ & \\
CANADA & 24 & $20.6897 \%$ & \\
AUSTRALIA & 7 & $6.0345 \%$ & \\
& 7 & $6.0345 \%$ & \\
ENGLAND & 7 & & \\
FINLAND & & & \\
& & & \\
& & & \\
& & Table 3. Analysis by Author & \\
\hline Author & & & \\
\hline & & & \\
PETTIGREW, KE & 7 & $6.0345 \%$ & \\
FISHER, KE & 6 & $4.1724 \%$ & \\
DURRANCE, JC & 5 & $4.3103 \%$ & \\
JAEGER, PT & 5 & $3.4483 \%$ & \\
BURNETT, G & 4 & $3.4483 \%$ & \\
CHOO, CW & 4 & $3.4483 \%$ & \\
JULIEN, H & 4 & &
\end{tabular}

Table 4. Analysis by Document Type

\begin{tabular}{llll}
\hline Document Type & Record Count & $\%$ of 116 & Bar Chart \\
\hline & & & \\
ARTICLE & 74 & $63.7931 \%$ & \\
PROCEEDING PAPER & 23 & $19.8276 \%$ & \\
REVIEW & 19 & $16.3793 \%$ & \\
& & & \\
\hline
\end{tabular}




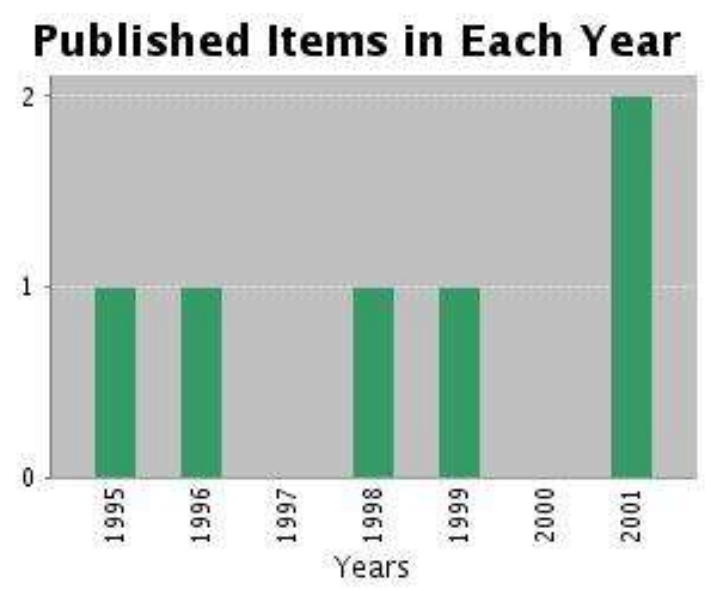

Figure 1.

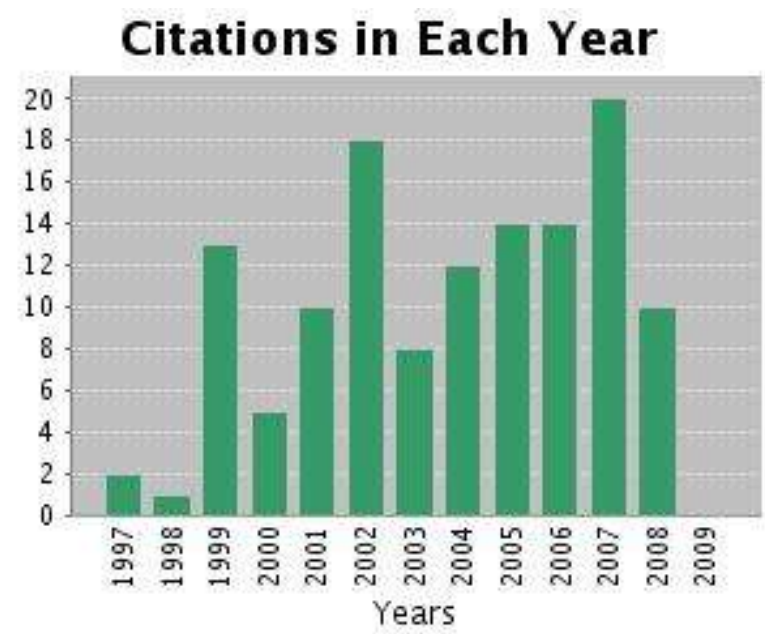

Figure 2.

\section{Conclusion}

The report has aimed to clarify Elfreda A. Chatman's role on the information science. Chatman studied information seeking behavior and information poverty. She generally focused on ordinary and poor people such as retired women, prisoners, lesbians, janitors and librarians. Chatman made studies in prisons, universities and booksellers in order to determine those groups' approach about their needs of information and to seize their information seeking behavior. Chatman concluded that in the small communities, information is usually not adopted from outside, and the process of information seeking is considered as prescriptive. Also, normative behaviour entails upon individuals' general attitudes that belong to the community by using social norms. She used other disciplines' theories in the beginning. After noticing the theories; deficiency to explain information seeking behaviour she produced her theories.

Therefore, she contributed to the field of information science by introducing new theories. That is the reason why the most cited works of Chatman are the articles in which she introduced her theories. The researchers who have mostly cited Chatman studied information science, library science, computer science and information systems. The consequence is that her studies are essential for library and information science. It was useful to benefit from several citation analysis tools because one citation tool does not mostly cover all kinds of data about the author or her works. Chatman's works have been evaluated based on citation accounts, years, location and subject. It can be inadequate to reflect her role in this field completely. In particular, her studies 
Eren, M. E. (2016). An author report: Elfreda Annmary Chatman. International Journal of Human Sciences, 13(1), 844-850. doi:10.14687/ijhs.v13i1.3642

about social problems and theories can be helpful for other disciplines if they are evaluated well. As a result, this field needs further studies that can focus on the contents of her theories.

\section{References}

Burnett, G., Besant, M., \& Chatman, E. (2001, May). Small Worlds: Normative Behavior in Virtual Communities and Feminist Bookselling. Journal of the American Society for Information Science \& Technology, 52(7), 536. Retrieved November 29, 2008, from Library, Information Science \& Technology Abstracts database.

Chatman, E A. (1987). The information world of low-skilled workers. Library \& Information Science Research 9, no. 4: 265-284. Library, Information Science \& Technology Abstracts, EBSCOhost (accessed December 1, 2008).

Chatman, E. A. (1990). Alienation theory: application of a conceptual framework to a study of information among janitors. RQ, 29(3), 355-368. Retrieved December 1, 2008, from Library, Information Science \& Technology Abstracts database.

Chatman, E. A. (1990). The information world of retired women. Greenwood Press.

Chatman, E., \& Pendleton, V. (1995). Knowledge gap, information-seeking and the poor. Reference Librarian, Retrieved December 1, 2008, from Library, Information Science \& Technology Abstracts database.

Chatman, E. (1996, March). The Impoverished Life-World of Outsiders. Journal of the American Society for Information Science, 47(3), 193-206. Retrieved November 29, 2008, from Library, Information Science \& Technology Abstracts database.

Chatman, E. (1999, March). A Theory of Life in the Round. Journal of the American Society for Information Science, 50(3), 207-217. Retrieved November 29, 2008, from Library, Information Science \& Technology Abstracts database.

Citeseer, (2008). Retrieved November 27, 2008, from http://citeseerx.ist.psu.edu.

Dervin, B. (1993, October). Reviews. Library Quarterly, 63(4), 532. Retrieved November 28, 2008, from Library, Information Science \& Technology Abstracts with Full Text database.

DBPL Author Search, (2008). Retrieved November 27, 2008, from http://www.informatik.unitrier.de

EBSCOhost, (2008). Retrieved November 29, 2008, from http://www.search.ebscohost.com.

Google Scholar, (2008). Retrieved November 29, 2008, from http://www.scholar.google.com.

IBEC, (2008), Retrieved November 26, 2008, from http://ibec.ischool.washington.edu.

ISI Web of Knowledge, (2008). Retrieved November 29, 2008, from http://www. isiwebofknowledge.com.

Pendleton, V., \& Chatman, E. (1998). Small world lives: Implications for the public library. Library Trends, 46(4), 732. Retrieved November 29, 2008, from Library, Information Science \& Technology Abstracts with Full Text database.

Portal, (2008). Retrieved November 29, 2008, from http://portal.acm.org.

WorldCat, (2008). Retrieved November 29, 2008, from http://www.worldcat.org. 